\title{
The Prince of Transylvania: Spanish News of the War against the Turks, $1595^{-1600^{*}}$
}

\author{
Carmen Espejo \\ Introduction
}

Among the most important news events in Europe in the early days of the Modern Age was the war against the Turks in the east. In Spain in particular, a set of news pamphlets addressing this topic is considered to be the first example of journalism in the full sense of the word. ${ }^{1}$ These were the news pamphlets published by the Sevillian printer Rodrigo de Cabrera between 1595 and 1600 about the exploits against the infidels of the Prince of Transylvania, Sigismund Báthory, along with other Christian knights. ${ }^{2}$ This is the first set of news pamphlets in which, although they had no fixed periodicity, each of the numbers was plainly part of a semi-regular series. In some of them, this is apparent in the titles, in which the pamphlets refer to themselves as the second, third, or fourth instalment of a numbered series relating to the same news.

After an extensive review of this corpus in collaboration with the project 'Biblioteca digital Siglo de Oro IV' I have managed to add to the number of news

* This paper is part of the Project Biblioteca digital Siglo de Oro IV (código FFI2012-3436), Ministerio de Economía y Competitividad del Gobierno de España, vi Plan Nacional de I + D + i 2008-2011. All translations are our own.

1 Sáiz emphasises the importance of this collection, but she describes it as "a series of annual news pamphlets named avisos", Ma Dolores Sáiz, Historia del periodismo en España. Los orígenes. El siglo XVIII (Madrid: Alianza, 1987), p. 35. Recently Domínguez has referred to Cabrera as a key figure for the beginning of Spanish journalism, Aurora Domínguez Guzmán, 'El preperiodismo en España a finales del Quinientos: las relaciones de sucesos impresas por Rodrigo de Cabrera', in De libros, lecturas y fiestas en la Sevilla áurea (Seville: Universidad de Sevilla, 2012), pp. 173-212.

2 News pamphlets on this war were not only published in Seville nor just by Cabrera. News about the conflicts between Christians and Turks in the Eastern frontier motivated numerous printed sheets in the latest years of sixteenth century in Spain, in cities like Valencia, Mallorca, and, to a lesser extent Granada and Saragossa, besides Seville.

(C) CARMEN ESPEJO, 2016 | DOI 10.1163/9789004277199_023

This is an open access chapter distributed under the terms of the Creative Commons Attribution-

Noncommercial-NoDerivatives 3.o Unported (CC-BY-NC-ND 3.o) License. 
pamphlets included. ${ }^{3}$ Thanks to the finding of hitherto little-known collections, we have been able to conclude that there are 30 news pamphlets surviving from those which Rodrigo de Cabrera published in Seville on the Turkish war. ${ }^{4}$ (This has allowed us definitively to add a small biographical detail to Cabrera's career, which is the fact that the Sevillian printer, whom most monographs suggest died in 1599, should be considered active until at least 1600, the date of his last surviving news pamphlet). ${ }^{5}$

However, the objectives of our work go further and seek to determine the channels through which information flowed in these first moments of modernity. We will use Cabrera as a case study for enquiring into the forms or formats (printed, handwritten, etc.) in which the news circulated, into the speed (frequency, the lapse of time between when events actually occurred and when they were reported, etc.) with which they were produced, and into the infrastructure that carried them (the postal service, and, principally, the agents who took on the task of reporting the news in a professional or semi-professional

3 The most important set of prints by Rodrigo de Cabrera about the Turkish wars is kept in the Real Academia de la Historia in Madrid. Another important set is kept in Biblioteca Universitaria de Sevilla. These collections and other minor ones have been described in repertoires and catalogues from the beginning of the 2oth century onwards: Uriarte describes 16 prints in the series; Agulló describes 20 and Domínguez 24; P.J.E. de Uriarte, Catálogo razonado de obras anónimas y seudónimas de autores de la Compañía de Jesús pertenecientes a la antigua asistencia española con un apéndice de obras de los mismos, dignas de especial estudio bibliográfico (Madrid: Sucesores de Rivadeneyra, 1906); Mercedes Agulló y Cobo, Relaciones de sucesos I: Años 1477-1619 (Madrid: Consejo Superior de Investigaciones Científicas, 1966); Domínguez, 'El periodismo'. Of late, Catálogo Colectivo del Patrimonio Bibliográfico Español (ССРв) has included a few more records, belonging to the same series about war in the Turkish frontier and not previously noticed. These records list the prints kept in Academia de Ciencias Morales y Políticas de Madrid, donated as part of the legacy of. D. Francisco de Cárdenas y Espejo. Cárdenas was the President of the Academia and passed away in 1989, and a famous Sevillian politician and scholar. He donated his rich library to the Academia. Our prints are to be found in a volume including 253 printed and handwritten documents, all of them from Seville, with a generic title "Relaciones históricas originales desde 1588 hasta 1631". I want to acknowledge the support and advice of D. Pablo Ramírez, librarian at Real Academia de Ciencias Morales y Políticas.

4 We have included an inventory of the series as an Appendix: Relaciones de Sucesos de Rodrigo de Cabrera sobre la guerra contra los turcos (1595-160o). A more exhaustive list is included in Domínguez, 'El preperiodismo', but she does not include some of the news pamphlets mentioned here.

5 The date of his death, 160o, is correctly pointed out in Domínguez, 'El preperiodismo', p. 175. See also Carmen Álvarez Márquez, La impresión y el comercio de libros en la Sevilla del Quinientos (Seville: Universidad de Sevilla, 2007). 
manner). Our starting hypothesis is that the European news system in the last decade of the sixteenth century was already sufficiently sophisticated for the catalysis of the dispersed practices of previous years into a solid business that definitely managed to captivate its readership. This system was sufficiently effective and flexible to transmit the news from one end of Europe, Transylvania, to the other, Seville in southern Spain, and even to the distant Americas. Thus, we affirm the claim of Arblaster:

The fact that all the newspapers studied adapted their news networks to these temporary developments in political affairs demonstrates both the effectiveness and flexibility of the postal-based news-writing system, and the extent to which all the editors shared common perceptions of what news was important.

Another aspect of the system's adaptability was the way that newswriters in the major centres passed on news not only from their own local contacts, but from all parts of the greater network to which they had access. The interlocking of information networks meant that public events in one part of Western Europe rapidly became public knowledge in all the others. ${ }^{6}$

Therefore our work offers to make a small contribution to the history of the earliest journalism of the modern age in Spain and Europe. We recognise two important limitations: the impossibility of retrieving the entire corpus of what was published, bearing in mind that much of the printed material must have been lost, and the difficulty of accessing some of those things that have been preserved, which we have been unable to study with our own eyes. This means that everything which follows has a provisional character and should therefore be treated more as a working hypothesis than as a definitive conclusion.

\section{Transylvania in the Spotlight of the First European Journalism}

Our microhistory of journalism begins in Seville in 1595 when Rodrigo de Cabrera published the first news pamphlet in the war against the Turks. ${ }^{7}$ This

6 Paul Arblaster, 'Post, Newsletters, Newspapers: England in a European System of Communications', Media History, 11: 1 (2005), p. 26.

7 A couple of news pamphlets devoted totally or partially to the conflict with the Turks were published in Valencia and Mallorca that same year of 1595: Copia de tres cartas venidas de Roma, del progresso de las cosas del Principe de Trâsilvania. Donde se vee lo que ha hecho en 
was a Carta de Mahomet Tercer Emperador de los Turcos, escripta al Serenissimo Segismundo Batori, Principe de Transilvania, Moldavia, Valachia, \&c. Traducida de lengua Turquesca en Lengua Italiana en Roma, en la Estampa del Gabia, en el Año de Mil y quinientos y noventa y cinco, in a pamphlet. If indeed this was the first printed news pamphlet to appear in the Sevillian market, it must have been quite surprising for its readers, because the letter had no introduction or other paratextual elements that let the reader know who were the correspondents, the sender or receiver of the letter, or the relationship between them. However, it must have been a success, because in the following year of 1596 the same printer published at least six more news pamphlets on the subject, in addition to republishing the letter. The licences at the end of each of these publications indicate that the licence was granted in the form of privilege for an increasing duration: one month for the first and second issues in the series; two months for the third; three months for the fourth, and so on. So the printer must have been afraid that, in those times of easy piracy, his successful venture would be infringed upon.

We know why that part of Europe monopolised the news of the time. Transylvania, the epicentre of most of the news, formed part of the kingdom of Hungary in the late sixteenth century. It was a principality of the Habsburgruled Holy Roman Empire, the same dynasty that reigned in Spain, and the Prince of Transylvania was married to Maria Cristina of Habsburg. In 1526, when the story begins, Transylvania was partially occupied by the Turks in one of their many attacks against Christian lands. From 1538, the Turks had also occupied Moldavia, and in 1541 they also took Buda and Pest. From 1591, the Prince of Transylvania, Sigismund Báthory, was part of a Holy League, led by

Moldavia, Valachuia, y Bulgaria, contra el Gran Turco. Y de la grande hambre de Costantinopla. $Y$ de dos embaxadas que el Turco embio al Principe de Transilvania. Cô; una victoria que el Principe ha alcançado de los Turcos. Yuna relacion sacada de las cartas que han venido de Paris (Valencia, Juan Navarro, 1595), UstC 351906; Copia de una carta del Conde de Fuentes Governador General de los estados de Flandes: embiada a los del Consejo destado de Bruselas, de la victoria que ha sido Dios servido de dalle contra el duque de Bullon y el conde de San Paulo, y monsieur de Villars, almirante de Francia. La qual sucedio a 24 de julio, vispera del glorioso Santiago patron de España.Juntamente con otro aviso de Ungria de otra victoria que se ha tenido contra el turco. Copia de carta del conde de Fuentes a los del consejo destado de Bruselas. Copia de carta de Oliver Pamiemsaco, para D. Juan de Tarsis correo mayor. Hecha en Milan, 16 de Agosto (Mallorca, Gabriel Guasp, 1595). The first, as can be deduced from the similarity of their titles, may have been based on the translation of avvisi published in Rome by Bernardino Beccari. In this paper we will focus on the circulation of Beccari's and others' avvisi to the Sevillian presses, but, if our hypothesis is right, it appears that Italian avvisi also circulated in Spain in other parallel ways, arriving at Valencia, for instance, through other correspondence networks. 
the Habsburgs, against the Turks, and which aimed to recover those territories in the so-called 'Long War', also called the "fifteen (1591-1606) or thirteen (1593-1606) years war". In January 1595, the year that interest in the subject was aroused in Spain, Sigismund signed a new treaty of cooperation with Vienna. Therefore, and although the land to be freed by the conflict was far away, this war had ingredients that brought it close to the interests of the Western Europeans: a dynastic solidarity and a religious background. ${ }^{8}$

To the natural public interest in this news should be added the propaganda effort of the authorities. Habsburg monarchs were certainly interested in publicising these campaigns as parallels to those waged against the same Turks in the Mediterranean a couple of decades earlier. Between 1570 and 1573, a Holy League was formed in Venice and, combined with the Papal States, Spain, and Portugal, defeated the Turks at the Battle of Lepanto, an immense victory for Christendom and the spur to a huge propaganda campaign. Moreover, a parallel conflict developed much closer to home as Spain confronted France (1590-98). The French conflict did not progress favourably for Spain, which was perhaps why it seemed doubly opportune to disseminate news of Habsburg victories in other conflicts. It is also likely that Báthory was interested in leaking news that was favourable to his reputation, given the internal problems he faced from the local nobility (which forced him to renounce the throne on three occasions). ${ }^{9}$

However, the information strategy could not have materialised at that time had there not been sufficient infrastructure in Europe to enable the movement of news from the eastern front to the cities of the West, even the most distant such as Seville. The 1590 s have been identified as the starting point of a robust communication network covering Europe, due to the establishment of international postal relays. ${ }^{10}$ In 1580 , this network was established in the territories of theSpanish Habsburgs, with Seville as its most southerly point. Consequently, the 1590 s was a good decade for the development of journalism, not only in Spain but also in other places and probably for the same reasons. For example, it was the period in which the publication of Mercurius Gallobelgicus started in

See Virginia Dillon, 'Transylvania in German Newspapers: Systems of Reporting and the News Stories of György II Rákóczi, 1657-58', in News in Early Modern Europe: Currents and Connections, ed. Simon Davies and Puck Fletcher (Brill: Leiden, 2014), pp. 58-79.

9 In one of the Spanish news pamphlets, based on an Italian aviso, a note apparently written by the Prince's secretary is transcribed, hence disseminating news of his own military campaigns: Segunda Relacion De los hechos y Vitorias del Serenissimo Principe de Transilvania (see Appendix), pp. 58-8o. UstC $35^{2692 .}$ 
Cologne, and in England the printer John Wolfe published a series of semiregular news sheets, Chiefe Occurrences. This has been identified by Raymond as "the first British periodical newspaper", on the basis of the same attribute of seriality that we have highlighted in the work of Rodrigo de Cabrera. ${ }^{11}$

However, these are still very general reasons to explain how it was possible that a modest printer in Seville had enough information to sell printed news on the subject to the public, with some regularity, for five consecutive years. ${ }^{12}$ Therefore we will now focus on the small network in which our printer moved and which enabled the appearance of journalism in Seville.

\section{The Italian Connection}

The first of the questions raised by this collection concerns the sources of information that the humble Sevillian printer had with which to devise his journalistic series. Our research has enabled us to discover that the core material of the accounts of Cabrera is an extensive series of Italian publications, published by at least two Italian novellanti, or newsmen. In fact Cabrera's texts indicate as much: the title of the Carta de Mahomet indicates that it is "Translated from Turkish language into Italian language in Rome" ("Traducida de lengua Turquesca en Lengua Italiana en Roma") and the Qvarta parte dela relación indicates in the colophon that it is "Printed in Rome with license from the Superiors. And now in Seville with license" ("Impresso en Roma con licencia de los Superiores. Y ahora en Sevilla con Licencia"). Moreover, the names of those reportisti serving as a source are declared in the headings of three of Cabrera's accounts:

Aviso del Aparato de la pompa y del numero de soldados con que Mehemet Rey de Turcos partio de Constantinopla para yr a la guerra de Vngria a los 20 de Iunio de 1596. Publicado por Bernardino Becheri, de Savile, a la Minerva, con licencia de los superiores en Roma, por Nic. Mutio, 1596.

Octava relacion y nuevos avisos de Alvaivlia, De primero de Mayo, deste Año de 1597. Por los quales se sabe, como la gente del Serenissimo Principe

11 Joad Raymond, Pamphlets and Pamphleteering in Early Modern Britain (Cambridge: Cambridge University Press, 2003), pp. 104-8.

12 Biographical and bibliographical information about Rodrigo de Cabrera is scarce. See, besides Domínguez 'El preperiodismo', Álvarez, La impression y el comercio. 
de Transilvania tomò dos fuerças muy grandes e importâtes, a los Turcos. Y de otras cosas particulares. Publicadas en Roma por Bernardino Becari a la Minerva. E impressas en Roma en la imprenta de Nicolas Mucio. En el dicho Año. Y por el mismo original sacadas de Italiano, en nuestro vulgar Castellano, en este mes de Iulio a veinte días del, y del dicho año.

La prometida de la vitoria que los capitanes del Emperador uvieron de los Turcos en el Danubio a los Veinte y uno de junio, deste presente Año de Noventa y nueve: Otros Avisos Nuevos, del dicho Año de Novêta y nueve, a los seys del mes de julio, venidos de la ciudad de Estrigonia a Viena, de otra Rota muy notable, que los Ayducos dieron a los Turcos, con la presa de Sacharet, y otros Castillos, dando libertad a quatrocientos y diez y siete Cautiuos, y el despojo que vuieron, de mas de un Millon de oro. Publicados en Roma por Geronymo Acolto con licêcia de los Superiores en casa de Nicolas Mucio. En este Año de 1599. Trasladado de Italiano bien y fielmente en nuestro vulgar Castellano.

The two named Italian reporters are, respectively, Bernardino Beccari and Gieronimo Accolti. ${ }^{13}$ Furthermore, because there are no surviving specimens of one of these news pamphlets and the other two are among those hitherto virtually unknown, becoming accessible only recently, no researcher has noticed the fact that the texts of Cabrera translated previous Italian texts of Beccari or Accolti. ${ }^{14}$

To date, we have been able to read only a very few Italian originals, so we have not been able to make a thorough textual collation. Even so, and based simply on the almost literal translations of the Italian titles into the Spanish texts, we can say that most of Rodrigo de Cabrera's news pamphlets appear to be based on translations of the avvisi of Bernardino Beccari and, to a lesser extent, on the translations of Accolti's avvisi. A few examples will suffice to prove the close relationship between these titles: the Quarta parte dela relacion nueva, De Transilvania y Valachia, Por la qual se avisan los prosperos sucessos del Serenissimo Principe de Transilvania contra los Turcos, assi enel un Reyno, como enel otro despues de la venida de la Corte del Emperador; desde primero de Mayo de 96 (USTC 351921) seems to derive its title from Beccari's publication Avvisi nuovi di Transilvania et di Vallachia per li quali s'intendono li prosperi successi del sereniss. principe contra turchi, printed in the same year, 1596 (USTC 812792).

\footnotetext{
13 The last one can be cited as Girolamo or Gieronimo Accolti.

14 See note 3 , above.
} 
This account also contains a story which is given a different heading, Nueva de la Rota hecha, de la gente de el Serenissimo principe de Transilvania a los Turcos y Tartaros junto a la Lippa con muerte de ocho mil de los Turcos y presa de tres Uchies, y toma de la Artillería y Vagajes, y de aver alçado el cerco; the title of which suggests it is based on Beccari's original Avvisi della rotta data dalle genti del sereniss. prencipe di Transilvania ai turchi, \& tartari a Lippa, con morte di ottomila di essi, presa di tre Behi, \& acquisto d'artiglierie, stendardi, bagaglie, \& leuata dell'assedio. Con altri avvisi nuovi di Valacchia (UsTc 812971).

The Relacion de todo el cerco de Temesuar, hasta q el Principe de Transilvania alço el Campo, por la qual se da cuenta de tres notables hazañas, que el mismo Principe hizo contra los Turcos y Tartaros. Yen particular la muerte del Tartaro Can, por mano de su Alteza del Principe, y del despojo del Canpo, y toma de lo que avia robado. Lo qual passo a 19. de Iunio de 1596 (USTC 351913), is another possible translation, this time of Beccari's title: Ragguaglio di tutto l'assedio di Temesuar. Fino alla levata del sereniss. prencipe di Transiluania da quella piazza, dove s'intendono tre notabili fattioni di sua altezza contra $i$ Turchi, et Tartari, et in particolare la morte del tartaro cane per mano dell'altezza sua, \& l'acquisto delle sue bagaglie, \& della preda che haueua fatta. Seguita a di 19 di giugno 1596 (USTC 813209).

These Italian journalists thus had a surprising international reach, and the stories they reported were translated or copied many miles away. We know little of Gieronimo Accolti: only that he was a schoolteacher and author of printed avvisi published in Rome. The repertoire of his avvisi about the Turkish war that we know of, and which starts in 1593, is probably very incomplete. One of his avvisi has found new publishing fortune today through several reprints, the Avviso nuovo di Transilvania: Nel quale S'Intende la Rotta di Venticinque mila Turchi, data dal Serenissimo \& Invittissimo Prencipe di Transilvania. ${ }^{15}$

We know a little more of Bernardino Beccari. Beccari was an Italian bookseller, publisher and journalist in the second half of the sixteenth century. The known biographical data has him born in Sacile, in what was then the March of Treviso, and therefore very close to Venice, a key connection between West and East. In 1575, he was authorised to open a bookstore in the Piazza della Minerva in Rome. As Bulgarelli indicates, Beccari is best

\footnotetext{
15 See for instance, Gieronimo Accolti, Avviso Nuovo Di Transilvania: Nel Quale S'Intende La Rotta Di Venticinque Mila Turchi (Whitefish, мт: Kessinger, 2009).
} 
remembered as the author of numerous news pamphlets, i.e., as a writer of printed avvisi, mostly published in the press of Nicolò Muzi in Rome. ${ }^{16}$ Bulgarelli also notes that despite an eighteenth century historian recording him as the author of eleven avvisi between 1595 and 1599, the data is incorrect as there are over fifty copies of Beccari avvisi in the libraries of Rome alone. We ourselves, after a quick search, have located up to 49 avvisi solely among those dedicated to the Christian-Turkish wars of the late sixteenth and early seventeenth centuries. Bulgarelli considers him "the precursor of the Italian journalist", and says of him:

L'opera del B., come redattore di avvisi, ha un'importanza veramente notevole dal punto di vista della storia del giornalismo. Prima di lui gli avvisi a stampa avevano un carattere del tutto occasionale: si trattava quasi sempre di lettere private, scritte da diversi, e spesso anonimi autori, le quali-non sappiamo ancora bene attraverso quali vie ed accordi-venivano diffuse per mezzo della stampa. Il B. raccoglie invece le notizie - che a lui dovevano pervenire da varie fonti, ma soprattutto attraverso la rete dei corrieri postali-e le elabora in veri e propri articoli che hanno già uno spiccato sapore giornalistico. ${ }^{17}$

(The work of B., as an editor of avvisi, has a remarkable importance from the point of view of the history of journalism. Before his printed avvisi they were always occasional in character: they were almost always from private letters, written by different, and often anonymous authors, which - we do not yet know by what means and arrangements-were widespread in the press. B. instead collects news items-that he had received from various sources, but mainly through the network of the post carriers-and combines them into real products that have a strong journalistic flavor.)

16 Bulgarelli mentions that he is mainly known as an editor for Il Prencipe by Fracastoro, but we think this may be an error; Bulgarelli probably refers to the edition of Il Prencipe by Frachetta, about which we will talk below. Tullio Bulgarelli, Dizionario Biografico degli Italiani, 7 [1970], <www.treccani.it/enciclopedia $>$ [21/9/12]. See also Tullio Bulgarelli, Gli avvisi a stampa in Roma nel Cinquecento. Bibliografia, antología (Rome: Istituto di studi romani, 1967) and Tullio Bulgarelli, 'Bernardino Beccari da Sacile antesignano dei giornalisti italiani', Accademie e Biblioteche, 34 (1966), pp. $123-35$.

17 'L'antesignano dei giornalisti italiani'. Bulgarelli, Dizionario Biografico. 
Although he wrote avvisi on various international news topics of the day, his speciality was without doubt the news of the conflict with the Turks in the Balkans. ${ }^{18}$ He began to be interested in the subject in 1593, just as the Thirteen Years War broke out; or at least his oldest printed avvisi that we know of, on any subject, are from that date. In that year he wrote at least two printed avvisi: a copy of one was printed in Rome (from the press of Luigi Zannetti) and copies of the other in Rome and Naples. One of them is called Auiso d'una rotta data dalle genti di sua maesta cesarea, so this early instantiation of the first journalistic genre of the Modern Age used in its title the name by which it would be recognised across Europe. ${ }^{19}$ Although it is not the only name with which his pamphlets were titled, it is the most frequent in his production.

The following year, 1594, we know of two Beccari avvisi on the same conflict in the Balkans and also published by Zanetti's press in Rome. A version of one of them, Auisi nuoui della rotta data dal general superiore al beglierbei della Grecia, was published in Verona, and the imprint of this, in turn, indicates that it was also a reprint of the same in Bologna. There can be no doubt then that Beccari's avvisi had immediate success and circulated widely in Italy.

Furthermore, the information explosion arrived the following year, 1595, the year in which Báthory signed a treaty with the Holy League, and when Beccari issued at least thirteen publications about the news that concerns us. Of these, two publications reproduce orationes, or speeches, written by Girolamo Frachetta and addressed to the Christian Prince of Transylvania, Sigismund Báthory, urging him to continue the war against the infidel Turks. We should remember that these orationes were a popular genre in the political writing of the first modern age.

Although in this case it is not news as currently conceived, these letters are of interest to our research because they can help us reconstruct the clientbased network through which developments on the eastern front were able to reach Beccari, and from thence, as discussed below, to other European enclaves. We have indicated that the letters or orationes are the work of Girolamo Frachetta da Rovigo: he was a philosopher, political writer and member of the Accademia degli Incitati of Rome. The journalist, Bernardino Beccari, was editor of at least three of Frachetta's works, two of which were published in the

18 Beccari, like Accolti, has had a renewed editorial success lately: see for instance Bernardino Beccari, La Solenne Entrata Che Ha Fatto Il Signor Conte Di Lemos, Vicer Di Napoli, in Roma Alli 20. Marzo 16oo: Con La Caualcata Di S. Eccel. Al Concistoro Publico, Che Fu Alli 22. Dell'istesso Mese (Charleston, sc: Nabu Press, 2010).

19 Most of the avvisi of Beccari and Accolti are registered in EDIT 16 Censimento nazionale delle edizioni italiane del XVI secolo, <edit16.iccu.sbn.it>[21/9/12]. 
press of Nicoló Muzi in Rome. They are Il prencipe di Girolamo Frachetta nel quale si considera il prencipe \& quanto al governo dello stato, \& quanto al maneggio della guerra. Distinto in due libri, en 1597 (USTC 803483); Il primo libro de i discorsi di stato \& di guerra. Di Girolamo Frachetta ... Con tre orationi nel genere deliberativo del medesimo autore, in 1600 (USTC 830487); and, more interesting to us, Il primo libro delle orationi nel genere deliberativo di Girolamo Frachetta scritte da lui a diversi prencipi per la guerra contra il Turco. Con gli argomenti a ciascuna oratione, del medesimo autore (USTC 830485), in 1598, a work in which Frachetta probably collected his speeches, some of which, as we have seen, had been previously published as pamphlets by Beccari.

Frachetta, a writer of some repute therefore, was in the service of Cardinal Luigi d'Este, and later of Scipione Gonzaga, Cardinal and Patriarch of Jerusalem. It is plausible that the two dignitaries, and also Frachetta on their behalf, correspond to the type of regular clients of the handwritten newsletter networks described by Mario Infelise. ${ }^{20}$ In our hypothesis, these could have been the final recipients of the handwritten avvisi that came to Beccari from the front. The reportista Beccari, related to that circle because, as we have seen, he edited the orationes from Frachetta, also edited and printed the news of Transylvanian wars to which that circle had access, probably with its consent.

Whether or not that was the network through which news came to him, in addition to these two "speeches", Beccari issued at least eleven more publications on the Turkish wars throughout 1595. Of these, nine are titled avvisi or avviso and only one relatione. We found that most of them had reissues or reprints in Italian cities other than Rome, confirming the commercial success of the series. The thirst for information about the adventures of the Prince of Transylvania and other Christian military leaders appears to have erupted in the summer of 1595 . According to information provided by their titles, most of these publications were issued between late June and mid-November. The fact that some avvisi reporting a victory on 15 August were sent to Rome on the sixteenth provides an idea of this fervour for topicality, and this point is reflected in the title: Avisi di Alba Giulia delli 16 d'agosto 1595 Dove s'intende le nozze del serenissimo prencipe di Transilvania fatte a di 6 d'agosto, \& una segnalata vittoria diS.A. contra Turchiottenuta alli15 dell'istesso mese (USTC 852257).

In the following years Beccari would continue publishing avvisi on the same subject: we know of 14 from 1596, four from 1597, six from 1598, six from 1599 and two from 1600 , the year of the author's disappearance.

20 Mario Infelise, Prima dei giornale. Alle origine della pubblica informazione (Rome and Bari: Laterza, 2002). 


\section{Juan de Mosquera: The Network's Reporter}

Having located some of the agents of the micro-network that supplied Rodrigo de Cabrera, the question now is how these Italian avvisi arrived at the presses of the Sevillian typographer. Careful reading of the Spanish texts allows us to conclude that the next element in the network that brought news from Transylvania to Seville was Juan de Mosquera, a Spanish reporter who, while temporarily resident in Rome, ${ }^{21}$ received regular Italian printed avvisi, translated them, and used them to construct his own stories. In fact Mosquera's name is also mentioned by Cabrera himself, but only in one of the stories, the third, which indicates in its header: Tercera Relacion de lo sucedido al Principe de Transilvania desde catorze de Março de noventa y seys hasta. 27, de Abril del dicho año, con los de mas sucessos que al Emperador de Alemania an sucedido, y las Ciudades que a ganado al gran Turco, assi en la Dalmacia, como la tierra adentro de Turquia. Embiada por el hermano Juan Mosquera para el padre Provincial del Peru, su fecha en seys de Mayo de, 1596. (USTC 531922).

Who was Juan de Mosquera? In all likelihood he was a Jesuit, coadjutor of the order, known in Spanish literature for an extensive work, Historia de este Colegio de la Compañía de Jesús de Madrid, dividida en II libros en los cuales se contienen las cosas memorables que han sucedido en él desde el año 1547 ... hasta el de 160o, which was commissioned by the Vice-Chancellor of the College of Alcalá de Henares. ${ }^{22}$ According to Domínguez, he became copyist to the Superior General of the Society, Claudio Acquaviva. ${ }^{23}$ Thus he was both

21 The location of Mosquera in Rome was already mentioned by Uriarte, in his comment to Segunda relación: "es posible que existan más [relaciones] de las que allí se apuntan, dado que realmente se imprimieron todas las que enviaba de Roma el H. Mosquera" ("it is possible that there are more relaciones than the ones mentioned there, given the fact that all the ones that Brother Mosquera sent from Rome were published"). Uriarte, Catálogo razonado, p. 172. He borrowed this idea from a handwritten note in one of the copies kept in Real Academia de la Historia de Madrid: “avisa el P. Rafael Pereyra que este $\mathrm{h}^{\circ}$. Mosquera imbiò de $\mathrm{R}^{\mathrm{a}}$. Asta una dozena de relaciones de las cosas del Turco, con la carta de Mahometh al príncipe de Transylvania,y otros avisos muy curiosos, que todos se imprimieron aquí en Seva". ("Father Rafael Pereyra highlights that this Brother Mosquera sent from Rome until a dozen of news pamphlets about the matters of the Turk, with the letter of Mahometh to the Prince of Transylvania, and other very interesting news, an all of them were printed here in Seville"). Uriarte, Catálogo razonado, p. 202.

Domínguez, 'El preperiodismo', p. 183. 
chronicler and copyist, and we know that both offices were very close to that of a journalist or reporter in the early days of European journalism.

The bibliographical reference works weigh this information differently. For Uriarte, Mosquera was a "translator" of Cabrera's publications, although he does not identify the original works that were translated. ${ }^{24}$ In the rest of the bibliographies or catalogues this attribution is repeated, and habitually, Mosquera is mentioned as either a "translator" or an "author". ${ }^{25}$ Nevertheless, it is still necessary to clarify the role of Mosquera in the production of the Spanish news pamphlets about the Turkish war to determine whether he was merely translating the texts of Beccari, Accolti and perhaps others, or whether he became a more complex figure, that of journalist or journalistic editor. From a careful reading of the texts we have deduced that the second option is more likely.

The journalistic series, whether its first number was Carta de Mahomet or the Relacion de lo sucedido al Serenissimo Principe Sigismundo Batori, begins in medias res, without any introduction or prologue. ${ }^{26}$ In this latter news pamphlet, an unnamed writer presents a series of avvisi about the conflict with the Turks, saying "Ase dicho aquí en Praga ..." ("as was said here in Prague"). It therefore appears that Mosquera begins his story translating the Italian pieces with little intervention; but for the subsequent news pamphlet, entitled Segunda Relacion De los hechos y Vitorias del Serenissimo Principe de Transilvania, he prefaces the story with a long prologue which, though unsigned, clarifies the context in which this correspondence is produced:

Pax Christi. Dende el Março pasado de Noventa y cinco comencé a tomar por asumpto el escrevir a V.R. cada mes, las Proezas, Hazañas, y cosas milagrosas, que el Christianissimo Principe de Trâsilvania, assi por sus capitanes, como por su persona avia hecho è iva continuando contra los Turcos ... Pero porque entiendo q se an perdido algunos Correos, maxime el de Noviembre y Diziembre, con quien enbiava la ultima de sus victorias, cô la tornada a Transilvania, con otras cosas memorables, dignas de saberse, y de alabar a Dios nuestro Señor, q tal animo y victoria le á dado; me à parecido no defraudara vras Reverencias el consuelo q de semejantes cosas se recibirá de tanta gloria de Dios y augmêto de su Santa Fè Catolica. Y assi en esta (sucintamente) aclararè parte de lo q iva con estos Correos, y proseguiré adelante con lo q a hecho después q entro y torno a

\footnotetext{
24 Uriarte, Catálogo razonado.

25 See for instance databases ССРв (Catalogo Colectivo del Patrimonio Bibliográfico Español) and BDRs (Biblioteca Digital Relaciones de Sucesos).

26 See note 7 , above.
} 
Alvajulia hasta, ahora, con los últimos avisos, q esta semana vinieron de Praga, de su llegada a aqlla ciudad a visitar al Emperador, y lo demás q a sucedido, porq entiendo será de mucho consuelo a todos.

(Pax Christi. As of last March 1595 I took the habit of writing to Your Highness every month and narrate the events, deeds and miracles that the Christian Prince of Transylvania had accomplished against the Turks, either by himself or with his captains ... But as it is my understanding that some messages have been lost, mainly those of November and December, where I gave an account about his last victories, with the conquest of Transylvania, with some other memorable things, well worthy to be known, and praising God our Lord, who such a courage and victory has given to him; It seemed to me that the relief that came from such things, such glory and augmentation of Catholic Faith, is not going to be disappointing for Your Highness. And so in this [letter] I will comment partly on the news of those messages, and I will proceed with what he has done since he entered Alvajulia and then came back, until now, with the last news, that came from Prague this week, about his arrival to this city to visit the Emperor, and the rest of things happened, because I guess it will be a great relief for everyone.)

The allusion to the recipient, identified as "VR" or "vras Reverencias" specifies the religious context in which the deeds of Báthory will be read; the choice of the protagonist is justified in the interests of the Society of Jesus:

estimando en mas la gloria y servicio de Dios nuestro Señor y la anplificacion de su Santa Iglesia, de q da muchas señales cada dia, y no fue pequeña la q dio entrando el Lipa, en ordenar q lo primero q se hiziesse en aqlla ciudad, fuesse un Colegio de la Côpañia ...

(better preferring the glory and service to God our Lord and the augmentation of his Holy Church, of which he gives many signs every day, not the least of which he gave upon entering Lippa, ordering that the first thing to be made in that city was a College of the Society ...)

The rest of the series fluctuates between the two possibilities already outlined: zero intervention by Mosquera, who in some numbers appears to simply translate the Italian originals; and full re-editing of the original accounts, summarising, interpreting, always accentuating a providential reading which was, in any case, already in the originals of Bernardino Beccari. In the Tercera Relacion de lo sucedido al Principe de Transilvania, Juan de Mosquera clarifies the terms of 
the commitment he has made with his correspondent: "Con el ordinario de Março escreui a V.R. y embiè los ultimos avisos que vinieron de Transiluania, agora no sabemos nada de alla, de que poder hazer larga relación. Pero dire en esta lo que uviere por no perder el curso de hazer esto cô todos los Correos" ("Last May I sent Your Highness the last avissi with news on Transylvania. We have no further news now but let me at least cover the issue, in order to comply with the habit of doing it with every mail"). It is precisely in the heading of this third news pamphlet that names of sender and recipient are given for the first and only time, "Embiada por el hermano Juan Mosquera para el padre Prouincial del Peru" ("Sent by Brother Juan Mosquera to the Provincial Father of Peru"). Therefore, this commitment could be understood as a gesture of respect or loyalty, and the information itself, the quantity or quality of information delivered almost as secondary issues. This series of texts is therefore framed within the usual practice of social and work relations in the early modern age, and has little to do with the passion for journalism that appears to have been aroused in Europe at the same time.

However, in this same third letter of Mosquera, and considering the probable delay in the arrival of the Italian avvisi, which until now had served as the vital source, the reporter intensifies his efforts to obtain any relevant information:

Con el Correo de Viena desta semana escriue el Agente del Archiduque Maximiliano que por allí acabaua de passar una estafeta de Principe de Transiluania con nueva de que ... (The Agent of Archduke Maximiliano informs us in the mail from Vienna this week that a post of Prince of Transylvania has just gone past with news of ...)

Por cartas de los nuestros de. 22. de Abril se tiene aviso ... (From letters of our people 22th April we know of ...)

In the numbers that follow, the writer continues to collect various sources and compare them to ensure their accuracy, as in the Sexta relación:

Vino esta nueva a Madrid por via de Venecia por muchas Cartas, y mexorose por via de Leon de Francia que dize lo mismo. Despues se ha confirmado esta nueva y mejorado por que escrive al Rey el Embaxador de Venecia, que es Don Ynigo de Mendoça, hermano del Marques de Mondejar, que tuvo Carta de Graz de la Serenissima Archiduquesa, que es la que a de ser suegra de nuestro Principe.

(News came from Madrid through Venice in many letters and it was further confirmed with letters from Lyon in France that report the same. 
Afterwards, the news item was confirmed again as the Ambassador of Venice, Don Ynigo de Mendoca, brother to the Marquis of Mondejar, writes to the King and he states that he received a letter from Graz sent by Archduchess, future mother-in-law to our Prince.)

The writer seeks to arrange his story, and the intervals between its delivery, so that the reader does not lose interest in the subject: "Despues de la Famosa, y memorable batalla de Agria, que fue a los 16. de Otubre, las cosas de la guerra, en Ungria, an estado muy quietas hasta agora" "After the Famous, and memorable battle of Agria, which happened on 16 October, war's matters, in Hungary, have been very quiet until now"); so begins the Octava relación.

Thus, it appears that the chronicler Mosquera became a self-conscious journalist, and even sensed the future possibilities of periodic information when he entitled his letters with ordinals: "segunda relación", "tercera relación", "cuarta parte de la relación", "quinta relación", "sexta relación", "relación séptima", "octava relación". ${ }^{27}$ One wonders why he stopped numbering his communications at this point, when he would still continue to write letters with news on the Turks for another two or three years. Perhaps it was because from then, in mid-1597, Mosquera started to alternate accounts of the Transylvanian conflict with stories constructed according to a new pattern. This developed the capacity for news of varying length, and concerning various international conflicts from various sources. In addition to the war against the Turks, Mosquera mainly introduces information about diplomatic conflicts between small Italian states and the wars against the French and the Flemish. This emergent genre, which was common in the Spanish press throughout the seventeenth century, was a prelude to the development of the gazette across the whole of Europe a few decades later.

The first printed series from Mosquera to fit this new generic mould reflects its heterogeneous content in its title: Relacion de lo sucedido en Frâcia, y Estados de Flandes, despues de la toma de Amiens: Y de lo que estos meses passados a sucedido en la corte del Principe de Transilvania, del Emperador, y del grâ Turco. Lo qual se sabe por Cartas de Roma, de tres de Mayo de este presente año de mil y quinietos y noventa y siete. This shift in his production can be interpreted in two ways. It is possible that Mosquera, from his previous experience as narrator of the Turkish wars, was becoming aware of the value of the information, and thus became a forerunner of the journalist, or perhaps he was

27 Nevertheless, we should remember that the title was often the work of the printer himself at the printing press at the time, so that in this case titles could have been written by Rodrigo de Cabrera — the printer—and not by Juan de Mosquera— the author/translator. 
simply urged by correspondents to expand the geographic scope of the news he supplied.

The strong dependence of these Spanish periodical pioneers upon Italian sources also occasioned lexical borrowing. Some of the Sevillian publications from 1597 are entitled "Aviso" or "Avisos"28 and these are some of the first occasions when this term of Italian origin, but perfectly meaningful in Spanish, was used as the name of a journalistic genre in the title of a publication. ${ }^{29}$

Was Mosquera then the sole author of all of Cabrera's texts? We cannot be sure at this point in our research. ${ }^{30}$ In fact, in at least two of the news pamphlets the printer indicates new names: Rodrigo Olea de Ossisinaga and Agustino del Olmo. ${ }^{31}$ We failed to find significant data on these two possible

28 Also in 1597 an Aviso venido de Roma, de la gran batalla auida cerca de Agria, ciudad de la Ungria superior entre los exercitos de la Magestad del Emperadory Serenissimo Principe de Transiluania, y el del gran Turco a Veynte y seys de Octubre de 1596 (Valencia: Herederos de Joan Nauarro, 1597) is published in Valencia.

29 We know of just one previous print headed by the term 'aviso': Avisos de la China y Iapon del fin del año de 1587, recebidos en octubre de 88, sacados de las cartas de los padres de la Compañia de Iesus que andâ en aquellas partes (Madrid: Viuda de Alonso Gómez, 1589), USTC 336979 . This header had appeared inside a title at least in a previous occasion: Carta venida de Pauia, de diversos y varios avisos de Constantinopla de la muerte de Selimo y dela creacion y coronacion de Armorad emperador Ottomanno de los Turchos. Con algunos avisos de la enfermedad que tuuo, y en siendo curado los presentes que mando enviar al santissimo sepulchro de nuestro señor Iesu Christo en Hierusalem. Con otras nueuas de la guerra entre el y el Sophiy de la armada suya, en Constantinopla alos. 26. de Abril de 1575 (Barcelona: Jaume Sendrat y Viuda Monpesada, 1575), USTC 351905. The appearance of the term 'aviso' referring to news arriving from the Turkish frontier allows us to put forward the hypothesis that this header came to Spain from Italy and in the framework of the interest aroused by this war against the Turks.

30 Uriarte provides the data to confirm our hypothesis that Mosquera was the author of all or almost all the news pamphlets in the Turkish war. In his comment on the news pamphlet Nuevos avisos. Venidos de Roma, 1599, he points out: "It has to be added to the others by Brother Mosquera, it is said handwritten in one of the copies in Biblioteca de la Historia, in Madrid" ('Hase de juntar con los demás del $H^{\circ}$. Mosquera, dice de mano uno de los ejemplares de la Biblioteca de la Historia, de Madrid', Uriarte, Catálogo razonado, p. 505).

31 The first of them, who Domínguez calls (with modern spelling) Olía de Osizenaga, is mentioned in the title Nuevos avisos venidos de Roma en este mes de Octubre a seys dias del. Y embiados a diez del mes passado de Agosto deste año de noventa y siete, por el Licenciado Rodrigo de Olea de Ossisinaga, al Padre Fray Alonso de aguilar, de la Orden de Sancto Domingo, a esta Ciudad de Sevilla. En que se da cuenta de las cosas que passan en Turquia. Y el segundo en Nuevas Que cuentan la Toma de Pappa, Fortaleza de Ungria ... Relacion del numero de los exercitos que se han de hallar en el Capo, en la Ungria, este presente Año en servicio dela Cesarea Magestad. Escripta por el Agustino del Olmo. Domínguez, 'El preperiodismo'. 
Spanish reporters. However, it is possible that from 1597, the Sevillian printer, after establishing his success in the market, made use of all the possible sources on the subject. It is also possible that there was more than one author whose texts were reproduced in the printed news pamphlets.

Whether Mosquera was the sole or the principal author of these texts, examining them allows us to understand the context in which this collection of information on such a distant war has a specific meaning. We have noted that Juan de Mosquera was a Jesuit: this precisely explains what enabled his correspondence. We know that the order of the Society of Jesus placed a significant emphasis on the importance of correspondence among its members, which was understood as additional proof of the obedience due to those more senior in the hierarchy. The famous "cartas de jesuitas" thus constitute a huge corpus of information about contemporary events which is an exceptional source for historians. If indeed Mosquera served as a copyist in Rome in the service of Superior General Acquaviva, he probably had access to letters and other information that came to the General.

However, more particularly, the correspondence between the Brother Coadjutor, Juan de Mosquera, and the Provincial Father of Peru is precisely explained. In 1595, the start date of the correspondence and of the publication of printed accounts, the Society had been re-established in Transylvania, and, judging by what we read in these same accounts, it was thanks to the Catholic zeal of Sigismund Báthory. This was not an easy process. The Jesuits were expelled in 1598, then readmitted in 1599, but they always fought against rejection from the Protestants of the region. In that inflamed religious climate, the news pamphlets of Juan de Mosquera acquired a flavour of religious propaganda to add to the political propaganda already pointed to above.

As already noted, the stories of Mosquera are imbued with providentialism, not unusual in early European news, and they expressly and repeatedly refer to the interests of the Jesuits. Essentially, however, it is one of the accounts which provides the framework of interpretation for the entire series: in Relacion verdadera del linaje y descendencia del Serenissimo Sigismundo Batorio, Principe de Transilvania, Moldavia y Valachia, sacadas de historias autenticas, y relaciones muy verdaderas, venidas de aquellas partes, con algunas de sus hazañas y proezas dignas de gran memoria, Mosquera, or whoever the author was, makes use of a lapse in the flow of news to issue a reminder of the exploits and virtues of the Prince, among which he emphasises the establishment of the Jesuit order in the troubled Transylvania: "La primera fue traer a los padres de la Compañía de Jesus a su Reyno" ("The first [deed] was bringing the fathers of the Society of Jesus to his kingdom"). 
Juan de Mosquera could have been urged by his correspondent, the Provincial Father of Peru, to report regularly on events in Transylvania and other parts of the world, as he had been requested to write the history of the Society around the same time; though it may simply have been a gesture of allegiance or friendship, which, as we know, was very common at the time. Nevertheless, this does not preclude us from attributing a clear journalistic vocation to Juan de Mosquera. As we have seen before, and if indeed he is the author of all or most of the texts, Mosquera often allows himself to be driven by informative zeal and the stamp of the epistolary genre disappears from his account. The first journalism was born of tentative attempts and made, as we know, by modifying prior textual assets. Moreover, the involvement of Mosquera with the subject, and his task as a reporter, did not end with the termination of the connection with Seville and the printer Rodrigo de Cabrera. Palau (1948-77) lists at least one other publication from to his pen about the Turkish wars, but published this time in Valladolid and Lisbon a few years later, in 1606, and again declaring the Italian source in its title: Relacion de la señalada y como milagrosa conquista del paterno imperio conseguida del serenissimo príncipe Ivan Demetrio, Gran Duque de Moscouia en el año de 1605 ... traduzido de Lengua Italiana. ${ }^{32}$

Therefore, we are almost at the end of the micro-network which connected Transylvania with Seville. We believe that it is perfectly possible that a Jesuit, seasoned in historical writing, resident in Rome, was dedicated to maintaining correspondence on the Turkish wars with a superior. Basing his stories on the printed Italian accounts that arrived by post, in addition to many other avvisi coming through this regular post or through special envoys, his position in the order would have allowed him access to these sources.

We must still ask ourselves what was the original format of Mosquera's letters or news pamphlets. As private correspondence, irrespective of whether Mosquera had the possibility of printing in mind or not, it is inevitable that they were initially circulated by post and in handwritten form. This raises a further question: how is it possible that, with only a few weeks delay, we know of them through printed versions, the work of a typographer who worked in distant Seville?33

32 Antonio Palau y Dulcet, Manual del librero hispano-americano: inventario bibliográfico de la producción científica y literaria de España y de la América Latina desde la invención de la imprenta hasta nuestros días, con el valor comercial de todos los artículos descritos (Madrid: Palacete Palau Dulcet, Empuries 1948-77).

33 This data is deduced from the lapse of time between the ending of the letters and the date in which the license for publishing was granted. It was usual to proceed with printing directly after this legal requirement was obtained. 


\section{From Transylvania to Peru}

Perhaps the explanation for this last point of our inquiry is at the other end of the postal correspondence, its recipient: the Provincial Father of Peru. For the dates of the published documents which concern us, this was Juan Sebastián de la Parra, who was born in Spain and died in Lima. He arrived in Peru in 1581 and was Provincial of the order there between 1592 and 1599, and later between 1609 and 1616. Among his achievements was the introduction of the Society of Jesus into Chile. At first it was Juan Sebastián de la Parra to whom these stories were addressed. As he resided in Peru at this time, letters sent from Madrid would have had to pass through Seville, where correspondence was gathered for transport to the Americas, the only Spanish port authorised for such traffic. It is not unreasonable to suppose that Rodrigo de Cabrera had someone close to the Jesuits among his contacts. In fact, his connection with them has been pointed out by scholars, which would have given him access to that correspondence and implied permission to print it. ${ }^{34}$ We must recall that this type of communication about contemporary politics had a semi-public character and the printing of the letters was not only common but also foreseen by the correspondents.

It is a little more difficult for us to understand why a member of a religious order, who was established in the distant lands of Peru, required such continuous and detailed information about a war that was going on at the other end of the earth, even if we accept that epistolary accounts were a hallmark of the Society of Jesus. What little we know of Juan de la Parra does not allow us to see him as an intellectual with deep humanistic concerns. Indeed, his fame among the Provincials of the order was due to his having promoted a statute of purity of blood to discriminate against new entrants into the order in Peru, because of his misgivings on seeing that Indians and persons of mixed race were ascending in the hierarchy. ${ }^{35}$ Of course, this gesture had little to do with the earlier Provincial in Peru, the celebrated Padre Acosta, author of the Historia Natural y Moral de las Indias, who, although he flatly asserted the superiority of the white race, at least showed some anthropological curiosity about the indigenous population.

34 Domínguez comments that his arrival to Seville, most likely from Madrid, is due to the call of the Jesuits, who asked him to produce some typefaces, and also points out that at least two prints, among the few large ones published by the printer, were the work of a Jesuit, Domínguez, 'El preperiodismo', p. 176.

35 See Alexandre Coello de la Rosa, 'De mestizos y criollos en la Compañía de Jesús (Perú, siglos XVI-XVII )', Revista de Indias, LXVIII, 243 (2008), pp. 37-66. 
It is also possible that the vision of a global world, which we believe a distinctive feature of our times, was already present or developing in the early modern period, and that contemporaries read accounts of distant wars with the same concern with which we read the international pages of newspapers today.

In any case, the Sevillian printer, Rodrigo de Cabrera, had access to a prodigiously detailed, accurate and important collection of information about the Thirteen Years War. The last element in this micro-network that we are describing concerns him. In this last stage of the analysis, we attempt to determine the degree of involvement of the printer in the final printed version.

In the first news publication of the series, the Relacion de lo sucedido al Serenissimo Principe Sigismundo Batori, he concludes with a colophon that already shows his advertising skills: "Lo que succedio después desto, y los Genizaros que le a muerto al Turco, y fortalezas que a ganado, se queda imprimiendo, que es cosa digna de saberse" ("What happened after this, as well as all the Turk's Janissaries killed by him and all the garrisons he has won is in print now, which is a thing well worth knowing"). From there on, numerous annotations, included in the colophons of the documents, allow us to believe that the printer, if indeed he was their editor, controlled from beginning to end the flow of information and the speed with which it reached the Sevillian market.

Between June and October 1596, and according to the dates of the licences, he printed at least seven news pamphlets on the subject. However, it is possible that the extent and chronological period covered by his stories do not correspond with those of the information that came to him from Rome by letter. The colophon of the Tercera relación states: "Lo de Iunio y Iulio de 96. q prosigue tras esto se imprimirá luego, Fin" ("The events of June and July that follows this will be printed now. The end"), and is followed in chronological order by two more documents covering the events of those months. The first, the Quarta parte dela relacion nueva, actually contains two stories, judging by their titles translated from Beccari's avvisi, each with its own heading, compressed into one document. The second is a brief account that barely covers a sheet and which tells of only one battle, again, we believe, based on a translation of Beccari. ${ }^{36}$ Our hypothesis is that all this information, corresponding to the months of June and July 1596, came in one shipment to Cabrera, in one of the letters from Juan de Mosquera, and that it was the printer who divided

${ }_{36}$ Italian and Spanish titles, above, can be compared. 
up the news for a series, surely quasi-periodic, by which means he kept his public waiting. ${ }^{37}$

One of the numbers of the series holds a surprise: the story is printed in two different versions or editions, with identical text, colophon and footnote, but different title pages. The text contains two main news items: a rebellion of Irish nobles in England, and the advances of Miguel de Bayboda against the Turks. In one of the title pages, the first report is highlighted in large characters, and in the other, the second report is similarly highlighted. Compare the two lengthy titles:

Avisos de Fuenterabia. En q se da quêta muy por estêso de cómo dos Côdes Yrlandeses, Catolicos, estâ reuelados côtra la Reyna de Inglaterra, y le an cercado la Ciudad de Catafurda, y le an muerto ocho mil soldados, y diez y ocho Capitanes. Escritos a cinco días de Abril deste año de 1599. Traslado de una carta del Señor Miguel Bayboda de Balachia, en la qual se da cuenta muy por estenso de todas las empresas, que a hecho contra el gran Turco en la Tracia y Bulgaria, desde que començo la guerra côtra los Turcos hasta que bolvio a Valachia. Y assi mismo se cuenta la destruicion de seys Ciudades, con otras muchas Aldeas, en la Tracia y Bulgaria, que este dicho Baiboda a hecho. La copia de la qual carta vino con el ordinario de Viena de los cinco de Diziembre, del año pasado de. 1598.

Traslado de una carta del Señor Miguel Bayboda de Balachia, que embio al Serenissimo Archiduque Maximiliano, en la qual da cuenta muy por estenso de todas las empressas, que a hecho contra el gran turco en la Tracia y Bulgaria, desde que començo la guerra côtra los Turcos hasta que bolvio a Valachia. Y assi mismo se cuenta la destruicion de seys Ciudades, con otras muchas Aldeas, en la Tracia y Bulgaria, que este dicho Baiboda a hecho. La copia de la qual carta vino con el ordinario de Viena de los cinco de Diziembre del año passado de 1598. Por Cartas de Fuenterabia se sabe como dos Codes Yrlandeses Catolicos, esta revelados cotra la Reyna de Inglaterra, y le an cercado la Ciudad de Catafurda, y le an muerto ocho mil soldados, y diez y ocho Capitanes. Y otros avisos dignos de saberse.

Since the date of the licence is the same for both documents, it follows that the twin publication could have been part of Cabrera's publishing strategy, who

37 Correspondence left Seville for America in an annual postal shipment which departed in July. Our correspondence may have followed this timing. Letters to America reached Seville mainly at the beginning of the summer. 
thus offered the same news with different emphases to two groups of readers in order to maximise sales. Moreover, this news pamphlet begins with a prologue in which an editor, perhaps Juan de Mosquera, the reporter, or Rodrigo de Cabrera, the printer, demonstrates his complicity with readers who already know the journalistic series: "Aunque se a escrito y impresso la mayor parte de las hazañas, que con tan felice y dichoso curso de fortuna a hecho y haze cada dia el señor Miguel Bayboda de Valachia en las tierras y estados del Turco con todo ello me a parecido sacar a luz una Carta que el dicho Bayboda escrivio al serenissimo Archiduque Maximiliano" "Although the deeds have been mostly narrated and printed, those which Sir Miguel Bayboda makes every day with such a happy and joyful fortune in the lands and states of the Turk, it occurred to me to bring to light a Letter which this Bayboda wrote to the Most Serene Archiduke Maximiliano").

Finally, how can the market success of this extensive series be explained? The insistence with which Cabrera boasted of the privilege obtained, advised his public of future issues coming up, and generally advertised his stories, allows us to imagine a public hungry for news, and perhaps pleasantly surprised by the new periodical form of publishing. Years before, the vicissitudes on the Turkish front had been the object of a large volume, the Commentarii della guerra di Transilvania (1563) by Ascanio Centorio de gli Hortensii, which we know was distributed in Seville through the city's bookshops. ${ }^{38}$ In any case, the Turks were already part of the popular imagination in Spain, thanks to a renewed interest in the topic through literature and the arts, especially after the Battle of Lepanto.

\section{Conclusions}

The handwritten letters from Mosquera in Madrid, constructed from Italian avvisi, printed in Rome and obtained from the battle-front of the Hungarian Empire, passed through Seville where they were converted into new stories printed in Castilian, and presumably then continued their journey to the Americas in their handwritten versions. This shift from manuscript to print is one of the constants of early European journalism, as is the interaction between agents with very different professional identities: the novellante in the

38 See Carlos Alberto González Sánchez and Natalia Maillard Álvarez, Orbe tipográfico. El mercado del libro en la Sevilla de la segunda mitad del siglo XVI (Gijón: Trea Editores, 2003). 
pay of the powerful; the writer embedded in networks of patronage who writes to his superiors as a sign of servitude; the pioneer printer who glimpsed the possibilities of the news business; and, in the background of everything, the religious and political powers that made use of the public's eagerness for news to maintain their own reputations.

Bernardino Beccari, in Italy, and Juan de Mosquera, in Spain, can be considered pioneers of journalism in their respective nations. These two pioneers were working at almost the same time and pace; the Italian had a couple of years' head start in product conception, while the Spaniard contributed ordinal numbering in the titles which confirms the emergence of a new written discourse in writing, the journalistic. From the start, the Italian used in almost all his publications the term 'avvisi', while the Spaniard called them 'relaciones' in the first year of production, and did not introduce the term 'avisi' until 1597. From then on this term was used in publications that related to news from other geographical areas.

The Italian notices are always headed by the word Aviso or Avviso, in uppercase, and a smaller font size than the second line. This foreshadows a more journalistic presentation, in the style of current headlines, while the Sevillian publications reiterate more obsolete presentations, close to those of the news pamphlets of the start of the century. Beccari's avvisi often carry the imperial shield with the double-headed eagle, which also appears on some Sevillian publications, although the Cabrera's series is not consistent in that respect. Some news pamphlets do not feature any engraving and those which do occasionally used different shields, others an allusive engraving, etc. Perhaps the conclusion we can draw from this point is that the Italian series was closer to officialdom than the Spanish, hence the most common appearance of the engraving of the Habsburgs arms.

Finally, in 160o, with the advent of the new century, both Italian and Sevillian journalistic series, closely related and both pioneers in the history of European journalism, ceased publication. Public attention to the Turkish wars declined (before returning to the foreground of topicality in the 1680s, when the Second Siege of Vienna resurrected the fear of the age-old enemy of the Christians).

The microhistoric approach has allowed us to reveal an international news network that worked effectively and quickly in the last decade of the sixteenth century. From this network, and many others working in unison throughout Europe, there soon appeared a landscape in which the emergence of regular reporting was possible, and this continued throughout the seventeenth century with a pan-European character, whose scope we have seen through our example here. 


\section{Appendix: News Pamphlets of Rodrigo de Cabrera on the War against the Turks (1595-160o)}

This includes all the news pamphlets by Cabrera concerning the war against the Turk in Spanish catalogues. Also those whose records are confused or refer to no longer extant prints.

1595

1. Carta de Mahomet Tercer Emperador de los Turcos, escripta al Serenissimo Segismundo Batori, Principe de Transilvania, Moldavia, Valachia, \&c. Traducida de lengua Turquesca en Lengua Italiana en Roma, en la Estampa del Gabia, en el Año de Mil y quinientos y noventa y cinco. Sevilla, Rodrigo de Cabrera [1595?, 1596?].

1596

2. Quarta parte dela relacion nueva, De Transilvania y Valachia, Por la qual se avisan los prosperos sucessos del Serenissimo Principe de Transilvania contra los Turcos, assi enel un Reyno, como enel otro despues de la venida de la Corte del Emperador; desde primero de Mayo de 96. Impresso en Roma con licencia de los Superiores. Y ahora en Sevilla con Licencia. Sevilla, Rodrigo de Cabrera [1596]. USTC 351921.

This includes: Nueva de la Rota hecha, de la gente de el Serenissimo principe de Transilvania a los Turcosy Tartaros junto a la Lippa con muerte de ocho mil de los Turcosy presa de tres Uchies, y toma de la Artillería y Vagajes, y de aver alçado el cerco. En este dicho año de noventa y seys, en el dicho mes de Mayo. Sevilla, Rodrigo de Cabrera [1596].

3. Quinta relacion de los prosperos sucessos: ansi del serenissimo Principe de Transilvania, como del exercito Imperial contra el gran Turco. Sevilla, Rodrigo de Cabrera [1596]. usTC 340199.

4. Relacion de lo sucedido al Serenissimo Principe Sigismundo Batori, Principe de Transilvania, Moldavia, y Valaquia, desde el principio del año passado de Noventa y quatro hasta ultimo de Otubre del dicho año. Sevilla, Rodrigo de Cabrera [1596]. UsTC 351912.

5. Relacion de todo el cerco De Temesuar, hasta q el Principe de Transilvania alço el Campo, por la qual se da cuenta de tres notables hazañas, que el mismo Principe hizo contra los Turcos y Tartaros. Y en particular la muerte del Tartaro 
Can, por mano de su Alteza del Principe, y del despojo del Canpo, y toma de lo que avia robado. Lo qual passo a 19. de Iunio de 1596. Sevilla, Rodrigo de Cabrera [1596]. UstC 352746.

6. Segunda Relacion De los hechos y Vitorias del Serenissimo Principe de Transilvania, que a tenido contra el Gran Turco. Donde se da cuenta de las grandes guerras que à tenido desde el principio del Año passado de Noventa y cinco, hasta fin de el mes de Março, deste Año de Noventa y seys. Con la declaracion de las Ciudades Castillos y Fortalezas que a ganado, en offensa del dicho gran Turco. Sevilla, Rodrigo de Cabrera [1596]. USTC 352692.

7. Tercera Relacion de lo sucedido al Principe de Transiluania desde catorze de Março de noventa y seys hasta. 27 , de Abril del dicho año, con los de mas sucessos que al Emperador de Alemania an sucedido, y las Ciudades que a ganado al gran Turco, assi en la Dalmacia, como la tierra adentro de Turquia. Embiada por el hermano Iuan Mosquera para el padre Prouincial del Peru, su fecha en seys de Mayo de, 1596. Sevilla, Rodrigo de Cabrera [1596]. ustc 351922.

\section{7}

8. Aviso del Aparato de la pompay del numero de soldados con que Mehemet Rey de Turcos partio de Constantinopla parayr a la guerra de Ungria a los 20 de Iunio de 1596. Publicado por Bernardino Becheri, de Savile, a la Minerva, con licencia de los superiores en Roma, por Nic. Mutio, 1596. Sevilla, Rodrigo de Cabrera, 1597.

9. Nuevos Avisos venidos de Roma en este mes de Octubre, a seys dias del. Y embiados a diez del mes passado de Agosto deste año de noventa y siete, por el Licenciado Rodrigo de Olea de Ossisinaga, al Padre Fray Alonso de aguilar, de la Orden de Sancto Domingo, a esta Ciudad de Sevilla. En que se da cuenta de las cosas que passan en Turquia. Y del Principe Cardenal, en Francia y otras partes. $Y$ de un presente que le embio el Biarnes Vandoma, al dicho principe y el principe Cardenal a el un muy buen cavallo. Ay aviso de cómo a salido el gran Turco con ciento y veinte mil soldados. Sevilla, Rodrigo de Cabrera, 1597. USTC 340333.

10. Nueva relacion venida de Roma este mes de Septiembre, deste año de 1597 de las grandes victorias que a tenido el Emperador contra el gran Turco, entre las quales le tomo una plaça de grande importancia, y de como murio el primogenito suyo, y otras desgracias que le an sucedido en daño suyo y provecho nuestro. Todo guiado por mano de Dios nuestro señor. Tambien ay avisos de Francia, y otras partes. Sevilla, Rodrigo de Cabrera, 1597. UsTC 345285.

11. Octava relacion y nuevos avisos de Alvaivlia, De primero de Mayo, deste Año de 1597. Por los quales se sabe, como la gente del Serenissimo Principe de Transilvania tomò dos fuerças muy grandes e importâtes, a los Turcos. Y de otras 
cosas particulares. Publicadas en Roma por Bernardino Becari a la Minerva. E impressas en Roma en la imprenta de Nicolas Mucio. En el dicho Año. Y por el mismo original sacadas de Italiano, en nuestro vulgar Castellano, en este mes de Iulio a veinte días del, y del dicho año. Sevilla, Rodrigo de Cabrera, 1597. UstC 338487 .

12. Relacion de lo sucedido en Frâcia, y Estados de Flandes, despues de la toma de Amiens: Y de lo que estos meses passados a sucedido en la corte del Principe de Transilvania, del Emperador, y del grâ Turco. Lo qual se sabe por Cartas de Roma, de tres de Mayo de este presente año de mil y quiniêtos y noventa y siete. Sevilla, Rodrigo de Cabrera, 1597.

13. Relacion Septima de la gran batalla que uvieron iunto a Agria ciudad de la Ungria Superior, los Exercitos de la Magestad del Emperador, y el Serenissimo Principe de la Transilvania, con el del gran Turco. En donde se avisa aver muerto setenta mil Turcos, y el saco de sus alojamientos, y los bagajes, con sola perdida de cinco mil Infantes y quinientos cavallos de los nuestros. Sevilla, Rodrigo de Cabrera, 1597. USTC 340201.

14. Relacion verdadera del linaje y descendencia del Serenissimo Sigismundo Batorio, Principe de Transilvania, Moldavia y Valachia, sacadas de historias autenticas, y relaciones muy verdaderas, venidas de aquellas partes, con algunas de sus hazañas y proezas dignas de gran memoria. Sevilla, Rodrigo de Cabrera, 1597. USTC 340202.

15. Sexta relacion de los prosperos sucesos y vitoria que agora nuevamente an alcançado el Serenissimo Principe de Transilvania, y el Exercito Imperial contra el gran Turco y su potencia, auida esta victoria dia de san Simon y Iudas en. 28. de Octubre de noventa y seys años. Sevilla, Rodrigo de Cabrera, 1597. USTC 351915.

1598

16. Avisos de Roma. De los sucessos del Ducado de Ferrara, desde la muerte del Duque Alfonso, hasta los partidos hechos entre su Santidad y don Cesar Deste, pretensor del dicho estado. Desde el mes de Noviembre passado, hasta diezy seys de Enero deste Año de 1598. Y la toma de la Ciudad de Temesuar, por el Principe de Transiluania, cô muerte de doze mil Turcos, y Vitorias alcançadas del Emperador de Alemania côtra el turco y sus Baxaes. Sevilla, Rodrigo de Cabrera, 1598. USTC 351262 .

17. Avisos de Ungria y de otras partes, por lo quales se sabe la Embaxada, que embiò el Rey de Persia, y de Sinan Can, Principe de Gorgiani, a su Cesarea Magestad. Con la Rota y estrago que los Polacos, y Valachios hizieron en los Tartaros, matando treinta y seys mil dellos. Y el aparato q se haze para yr a la conquista de Giavarino, y otros lugares. Traduzido fielmente de Lengua Tudesca 
en Italiana, en Milan, por Pandolfo Matatesta, con licêcia de los Superiores. Yagora en Sevilla impressa, con licencia de su Señoriay del Conde Assistente, en este mes de Febrero de Mil y quiniêtos y noventa y ocho. Por Rodrigo de Cabrera a la Magdalena, En la casa que era Espital del Rosario. Alli las venden. Sevilla, Rodrigo de Cabrera, 1598.

18. Avisos nuevos De la Victoria que agora de nuevo en este Año de Mil y quinientos y novêta y ocho, en el mes de Febrero a tenido Andrea Barchiasio, General del Serenissimo Sigismundo Batorio, Principe de Transilvania, en la ribera del Danubio, Contra el Sanjaco de Belgrado, en q le mataron mas de dozientos Turcos rôpiêdo a los demás. Y el gran despojo q tomarô de Cauallos enjaezados, y piedras preciosas. Y diez y ocho Estandartes. Y otras cosas de gran valor. Y la toma de la ciudad de Giavarino por su Magestad del Emperador. Impresso en Italiano en Roma, con licencia de los Superiores. Sevilla, Rodrigo de Cabrera, 1598.

19. Nuevas Que cuentan la Toma de Pappa, Fortaleza de Ungria. Con el numero de los Turcos que fueron muertos. Y otros successos de importancia. Y la gran rota, y desbarato, que los Cossaquios hizieron en los Tartaros. Y el apercibimiento del Exercito Imperial, para yr a cercar a Alva Real. Impresa en Milan por Pandolfo Mala testa, con licêcia de los Superiores. Yagora, en Sevilla impressa, con licencia de su Señoria el Conde Assistente, en este mes de Enero de Mil y quiniêtos y noventa y ocho. Por Rodrigo Cabrera, a la Magdalena, En la casa que era Espital del Rosario. Alli las venden.

This includes: Relacion del numero de los exercitos que se han de hallar en el Capo, en la Ungria, este presente Año, en servicio dela Cesarea Magestad. Escripta por el Agustino del Olmo, por la qual se sabra el numero y cantidad, no sola mente de la Cavalleria, sino tabiê de la Infanteria. Impressa en Ferrara, y en Verona, y en Milan Con licencia de los Superiores. Y ahora de nuevo impressa en Sevilla Con Licencia del Conde Assisetente En este mes de Enero, de 1598. Sevilla, Rodrigo de Cabrera, 1598. ustC 340198.

1599

20. Avisos de Fuenterabia. En q se da quêta muy por estêso de cómo dos Côdes Yrlandeses, Catolicos, estâ revelados côtra la Reyna de Inglaterra, y le an cercado la Ciudad de Catafurda, y le an muerto ocho mil soldados, y diezy ocho Capitanes. Escritos a cinco días de Abril deste año de 1599. Traslado de una carta del Señor Miguel Bayboda de Balachia, en la qual se da cuenta muy por estenso de todas las empresas, que a hecho contra el gran Turco en la Tracia y Bulgaria, desde que començo la guerra côtra los Turcos hasta que bolvio a Valachia. Yassi mismo se cuenta la destruicion de seys Ciudades, con otras muchas Aldeas, en la Tracia y 
Bulgaria, que este dicho Baiboda a hecho. La copia de la qual carta vino con el ordinario de Viena de los cinco de Diziembre, del año pasado de. 1598. ustC 345001.

21. Avisos venidos de Roma a los veynte y nueve de mayo deste presente año de. 1599. En que se escriven las nuevas que en aquella Corte avia avido en el dicho mes de Mayo, assi del Transilvano como del Bayboda de la Balachia, y de otros muchos Reynos y provincias. Con licencia impressos. Sevilla, Rodrigo de Cabrera, 1599.

22. La prometida de la vitoria qve los capitanes del Emperador uvieron de los Tvrcos en el Danubio a los Veinte y vno de junio, deste presente Año de Noventa y nueve: Otros Avisos Nuevos, del dicho Año de Novêta y nueve, a los seys del mes de julio, venidos de la ciudad de Estrigonia a Viena, de otra Rota muy notable, que los Ayducos dieron a los Turcos, con la presa de Sacharet, y otros Castillos, dando libertad a quatrocientos y diez y siete Cautivos, y el despojo que uvieron, de mas de vn Millon de oro. Publicados en Roma por Geronymo Acolto con licêcia de los Superiores en casa de Nicolas Mucio. En este Año de 1599. Trasladado de Italiano bien y fielmente en nuestro vulgar Castellano. Sevilla, Rodrigo de Cabrera, 1599.

23. La solene entrada que sus magestades del Rey y la Reyna nuestros Señores hizieron en la muy nombrada ciudad de çaragoça, Cabeça y Metropoli del Reyno de Aragon, a los doze deste presente mes de Septiembre, de este Año de Mil y quinientos noventa y nueve. Y el Recebimiento que se le hizo. Y los sumptuosos Arcos triunfales que uvo, y fiestas que se aprestavan. Y assimismo las nuevas que ay de Constantinopla, del Levantamiento de los Arabes contra el Turco. Y de la perdida que à hecho de la Arabia felice y de las Islas del Rio Eufrates. Y de la guerra que le an movido los Georgianos. Impresso en Sevilla en el dicho Año, por Rodrigo de Cabrera Impressor de Libros a la Madalena, en la casa q era Espital del Rosario, junto a Don jorge de Portugal. Alli las ay. Impressa con Licencia. Sevilla, Rodrigo de Cabrera, 1599.

24. La Vitoria que los capitanes del Emperador uvieron de los Turcos en el Danubio a los 21 de junio de 99. Otros Avisos Nuevos del dicho Año, venidos de Estrigonia de otra Rota, que los Ayducos dieron a los Turcos, con la presa de Sacharaty otros Castillos. Sevilla, Rodrigo de Cabrera, 1599.

25. Nuevos avisos, Venidos de Roma, de lo sucedido enel Exercito imperial, y lo que agora de nuevo à hecho el Serenissimo Segismundo Batorio, Principe de la Transiluania, y de otros avisos de diversas partes. Sevilla, Rodrigo de Cabrera, 1599. USTC 338479 .

26. Relacion de el fenecimiento de las Cortes de Barcelona, que su Magestad de el Rey nuestro Señor celebro a los Estados de Cataluña en este presente año, y de su partida para nuestra Señora de Monserrate, y despues para la ciudad de Tarragona, y de allí por La Mar a Valencia, con otras cosas. Y de una insigne vitoria que ha tenido contra los Turcos el Bayboda de la Valachia. Sevilla, Rodrigo de Cabrera, 1599. UsTC 352704. 
27. Relacion de las insignes victorias que han tenido los Exercitos Imperiales contra Turcos en Hungria, sucedidas en estos meses pasados de julio y agosto deste año de 1599. Sevilla, s.i., 1599.

28. Traslado de una carta del Señor Migvel Bayboda de Balachia, que embio al Serenissimo Archiduque Maximiliano, en la qual da cuenta muy por estenso de todas las empressas, que a hecho contra el gran turco en la Tracia y Bulgaria, desde que començo la guerra côtra los Turcos hasta que bolvio a Valachia. Yassi mismo se cuenta la destruicion de seys Ciudades, con otras muchas Aldeas, en la Tracia y Bulgaria, que este dicho Baiboda a hecho. La copia de la qual carta vino con el ordinario de Viena de los cinco de Diziembre del año passado de 1598. Sevilla, Rodrigo de Cabrera, 1598.

29. Verdadera relacion de la insigne victoria que Michael Bayboda (de la Balachia, ) Capita general del Serenissimo Principe de Transilvania a alcançado contra el Gran Turco, en la toma dela ciudad de Nicopoli, cabeça del Reyno de Vulgaria, con la muerte de quinze mil Turcos, y presa de ciento y quarenta pieças de Artilleria. Succedido todo en el mes de Setiembre, y Octubre del año passado de mil y quinientos y noventa y ocho, y otros avisos de diversas partes dignos de saber, como por ellos se vera. Sevilla, Rodrigo de Cabrera, 1599. USTC 340203.

1600

30. Relación de la Gran Batalla y Rota, que el Señor Miguel, Príncipe de la Valachia, a dado a Geremias, Principe y Vaivoda de la Moldavia. Amigo y aliado del Gran Turco. Y el numero desoldados Turcos y de otras Naciones, que fueron degollados y presos. Yotros ahogados y muertos en el rio Nesta; a donde también se ahogo el Vaivoda Geremias, y los otros Capitanes de su Exercito. Sucedido en el mes de Mayo de este Año de Mily seis cientos. Sevilla, Rodrigo de Cabrera, 1600. 